DOI : $10.14746 / \mathrm{pp} \cdot 2015.20 .2 .8$

\title{
Michał RADECKI
}

Opole

\section{Przyczyny zmian przywódców w partiach politycznych. Przypadek Polski}

\begin{abstract}
Streszczenie: Artykuł podejmuje kwestię przyczyn zmian przywódców w polskich partiach politycznych. Pod uwagę wzięto dwa główne czynniki, które - zgodnie z przyjętymi w środowisku naukowym poglądami - w sposób decydujący warunkują czas trwania na stanowisku. Po pierwsze, przeprowadzono analizę formalnych procedur związanych z odwoływaniem liderów partii politycznych zawartych w statutach partyjnych. Po drugie, przedstawiono wpływ wyniku wyborczego (uzyskane głosy i fakt zawiązania bądź nie koalicji gabinetowej) na zdolność liderów do utrzymania się na stanowisku. Analiza objęła partie polityczne, które uzyskały mandaty w wyborach do Sejmu przeprowadzonych w 2011 r., a więc Prawo i Sprawiedliwość, Platformę Obywatelską, Polskie Stronnictwo Ludowe, Ruch Palikota oraz Sojusz Lewicy Demokratycznej. Artykuł podejmuje zmianę przywódców od momentu powstania wymienionych partii. Analiza ujawniła silny wpływ uzyskanego wyniku wyborczego i rozwiązań statutowych na czas trwania liderów na stanowisku. Fakt zawiązania lub nie koalicji gabinetowej nie wpływa zasadniczo na utrzymanie przywództwa w partii.
\end{abstract}

Słowa kluczowe: przywództwo, partie polityczne, wybory, Polska, Europa Środkowo-Wschodnia

\section{Wstęp}

$\mathbf{W}$ yraźnym i zasadniczo niekwestionowanym trendem we współczesnych demokracjach jest wzrost pozycji liderów w ramach partii politycznych. Rośnie ich status jako szefów rządu, poszerzają oni swoją autonomię w ramach własnych ugrupowań, a także - choć w mniejszym stopniu - na nich skupiają się kampanie wyborcze (Poguntke, Webb, 2005, s. 337 i n). Niektórzy badacze uznają nawet, że partie polityczne i ich liderzy stają się pojęciami tożsamymi (Katz, Mair, 2002, s. 126). Pojawiają się ponadto nowe czynniki, jak europeizacja, które wzmacniają ich pozycję (Raunio, 2002). Istotny z tego punktu widzenia jest sposób, w jaki obejmują oni swoje stanowisko oraz z jakiego powodu je opuszczają.

Niniejszy artykuł podejmuje kwestię przyczyn zmiany przywódców w polskich partiach politycznych. Pod uwagę wzięto dwa główne czynniki, które - zgodnie z przyjętymi w środowisku naukowym poglądami - w sposób decydujący warunkują czas trwania na stanowisku. Po pierwsze, przeprowadzono analizę formalnych procedur związanych z odwoływaniem liderów partii politycznych zawartych w statutach partyjnych. Po drugie, przedstawiono wpływ wyniku wyborczego na zdolność liderów do utrzymania się na stanowisku. Analiza objęła partie polityczne, które uzyskały mandaty w wyborach do Sejmu przeprowadzonych w 2011 r., a więc Prawo i Sprawiedliwość (PiS), Platformę Obywatelską (PO), Polskie Stronnictwo Ludowe (PSL), Ruch Palikota (Ruch PL) oraz Sojusz Lewicy Demokratycznej (SLD). Artykuł podejmuje zmianę tendencji przywódców od momentu powstania wymienionych partii. 


\section{Przyczyny zmian przywódców w partiach politycznych}

Podobnie jak to uczynił Robert Michels formułując ,żelazne prawo oligarchii”, współcześni badacze partii politycznych generalnie przyjmują, że elity stopniowo ustanawiają kontrolę nad partią, kosztem aktywistów i zwykłych członków (Loxbo, 2013, s. 538). Badacze, którzy wysunęli tezę mówiącą o kartelizacji systemów partyjnych, utrzymuja że poprzez formalne wzmocnienie praw szeregowych członków partii, zostaje ograniczona rola, jaką pełnią lokalni aktywiści w podejmowaniu kluczowych decyzji, takich jak np. przyjmowanie programu wyborczego, rekrutacji elit (zwłaszcza parlamentarnych) czy wybór lidera partii (Katz, 2001, s. 290; Katz, Mair, 2009, s. 759; Mair, 1997, s. 113). Proponowane są jednak przeciwne interpretacje, w myśl których liderzy partyjni stają się bardziej otwarci na preferencje członków partii i elektoratu (Kitschelt, 2000).

Warto w tym miejscu odnotować studium przypadku analizujące demokrację wewnątrzpartyjną w Szwedzkiej Socjaldemokratycznej Partii Robotniczej (SAP). W świetle przeprowadzonych badań liderzy dysponowali mniejszą władzą, a aktywiści cieszyli się większymi wpływami w latach 90 . niż w okresie rozkwitu partii masowych w latach 50. (Loxbo, 2013, s. 549). Niezależnie od roli, jaką przyznaje się badaniom typu studium przypadku w falsyfikowaniu teorii (Flyvbjerg, 2005; Lijphart, 1971, s. 692), analiza demokracji wewnątrzpartyjnej w SAP dowodzi, że autonomia przywódców we współczesnych partiach nie powinna być przeceniania.

W odniesieniu do Wielkiej Brytanii, Stuart McAnulla wskazał na cztery trendy, które przyczyniają się do wymuszania odejścia partyjnych liderów. Odnoszą się one do: 1) wzrostu znaczenia, jakie przypisuje się liderom; 2) postępującej ,celebrytyzacji” polityki; 3) erozji granic dzielących życie publiczne i prywatne oraz 4) profesjonalizacji polityki (2010, s. 593).

W świetle systematycznych badań nad wpływem wyniku wyborczego na zdolność liderów partyjnych do utrzymania się na stanowisku, wyłania się czytelny wzorzec usuwania nieefektywnych przywódców (Andrews, Jackman, 2008, s. 674). Dla dużych partii strata mandatów w parlamencie wiąże się z pozbawieniem lidera stanowiska; prawdopodobieństwo odejścia lidera zwiększa się jeszcze bardziej, gdy dana partia nie wejdzie do rządu. Inaczej mówiąc, kariera przywódców jest niezagrożona dopóki partia zwiększa liczbę mandatów w parlamencie, a przywódcy stają na czele rządu. Kariera przywódców małych partii jest silnie powiązana z wynikiem wyborczym, który z kolei przekłada się na liczbę obsadzonych mandatów. Na tę kwestię, inaczej niż na wejście do rządu w charakterze partii dopełniającej, liderzy małych partii mają stosunkowo duży wpływ. Słaby wynik wyborczy i w jego wyniku słaba pozycja w parlamencie może przez to położyć kres karierze przywódców małych ugrupowań (Andrews, Jackman, 2008, s. 674-675).

Analiza przyczyn odwoływania liderów Duńskiej Partii Socjaldemokratycznej wykazała z kolei, że wynik wyborczy odegrał częściową rolę w usunięciu jednego lidera na trzy przypadki zmiany na stanowisku przewodniczącego. Cztery porażki wyborcze nie pociągnęły za sobą zmiany przywódcy. Dominującą przyczyną zmian był fakt niewejścia do rządu (Bille, 1997, s. 389).

Poza analizę czynników instytucjonalnych i sytuacyjnych wyszli badacze, którzy wysunęli koncepcję, która przyjmuje, że na czas trwania kadencji wpływa sposób postrzegania liderów przez podmioty mające prawo do usunięcia ich ze stanowiska. Propozycja ta 
opiera się na założeniu, że podmioty decydujące o długości kadencji oceniają obecnego lidera w odniesieniu do jego bezpośredniego poprzednika. W ten sposób kadencja liderów obejmujących stanowisko po odejściu długoletnich skutecznych przywódców jest krótsza niż liderów, którzy pełnili swoją funkcję po mniej efektywnych przywódcach (Horiuchi, Laing, 't Hart, 2012, s. 1-2).

\section{Hipotezy badawcze}

Pierwsza hipoteza odnosi się do wpływu formalnych procedur ujętych w statutach partyjnych związanych z odwoływaniem lidera. Opiera się ona na założeniu, że rozwiązania instytucjonalne mają istotny wpływ na długość kadencji lidera.

$\mathrm{H}_{1}$ : Zapewnienie dużej rozliczalności lidera przed partią będzie powodowało częstsze sięganie po formalne mechanizmy umożliwiające skrócenie kadencji lidera.

W tak zarysowanym podejściu, instytucje określone w statutach partyjnych dostarczają informacji o prawdopodobnym zachowaniu. Wpływ formalnych reguł wyłaniania i odwoływania przywódców jest zwykle akcentowany jako czynnik wpływający na realizowanie przywództwa w ramach partii politycznych (Bynander, 't Hart, 2007, s. 49; Cross, Blais, 2011, s. 147; McSweeney, 1999; Quinn, 2005).

Szacowanie stopnia rozliczalności lidera przed partią polityczną nie może opierać się jedynie na prostym zliczeniu, ilu liderów zostało usuniętych ze stanowiska. Jest tak, ponieważ liderzy, zdając sobie sprawę z instytucjonalnych mechanizmów mogących położyć kres ich przywództwu, podejmują kroki zaradcze, by zapewnić sobie silniejszą pozycję w partii (Weller, 1983, s. 98). Funkcjonowanie mechanizmów zapewniających większą rozliczalność może jednak zachęcać wewnątrzpartyjną opozycję do prób usunięcia przywódcy. W ten sposób zarówno udane, jak i niezakończone sukcesem próby odwołania lidera w oparciu o istniejące zapisy statutowe, zostały potraktowane jako rzeczywisty miernik wpływu rozwiązań instytucjonalnych na długość kadencji lidera. Analiza w tej części opiera się o analizę statutów partyjnych.

Funkcjonowanie partii politycznych motywowane jest wieloma czynnikami. W literaturze wymienia się w szczególności maksymalizację głosów w wyborach, udział w rządzeniu, czy realizowanie programu wyborczego (Harmel, Heo, Tan, Janda, 1995, s. 3; Harmel, Janda, 1994, s. 269; Helboe Pedersen, 2012; Müller, Strøm, 1999). Druga i trzecia hipoteza odnoszą się do kryzysu, jaki może się wiązać z przegranymi wyborami. Ogólnie można stwierdzić, że niezadowalający wynik wyborów będzie wiązał się z odejściem lidera ze stanowiska.

$\mathrm{H}_{2}$ : Uzyskanie przez partię słabszego wyniku w wyborach parlamentarnych doprowadza do odejścia lidera ze stanowiska.

$\mathrm{Na} \mathrm{rzecz} \mathrm{pozytywnej} \mathrm{weryfikacji} \mathrm{H}_{2}$ powinien działać fakt, że polskie partie polityczne otrzymują finansowanie z budżetu państwa, które jest zależne od wyniku wyborczego, co promuje partie cieszące się znacznym poparciem wyborczym. W ten sposób liczba uzyskanych mandatów bezpośrednio rzutuje na stan partyjnych finansów. Inne formy zasilania kas partyjnych, niepochodzące z budżetu państwa, jak np. składki członkowskie 
stanowią niewielki odsetek finansów partyjnych (Radecki, 2012, s. 93-94). Za wskaźnik słabego wyniku wyborczego przyjmuję uzyskanie mniejszego odsetka głosów w wyborach niż we wcześniejszej elekcji. Umożliwia to zastosowanie tych samych wyznaczników poparcia społecznego w kolejnych wyborach parlamentarnych. Za dodatkowy miernik, ze względu na częste na początku polskiej transformacji ustrojowej zmiany w ordynacji wyborczej, przyjmuję uzyskaną liczbę mandatów w poprzedzającej elekcji. Należy zaznaczyć, że podejście bazujące na liczbie uzyskanych głosów czy mandatów, choć często stosowane w literaturze, może być niewystarczające. Wynika to z faktu, że istotniejsze wydają się oczekiwania partii i subiektywny odbiór wyniku wyborczego (por. Harmel, Heo, Tan, Janda, 1995, s. 26; Laing, Hart, 2011, s. 115). Można sobie wyobrazić sytuację, w której faworyt wyborów uzyskuje wynik słabszy niż oczekiwano, bądź mniejszy niż w innych wyborach np. prezydenckich bądź do samorządu terytorialnego. Słaby wynik wyborczy może być ponadto niwelowany faktem wejścia do koalicji gabinetowej. W ten sposób, biorąc pod uwagę, że w Polsce rządy mają w przeważającej mierze charakter koalicyjny, wejście w skład rządu umożliwia prowadzenie polityki patronatu i czerpanie zysków ze sprawowania władzy. Hipotezę odnoszącą się do areny rządowej można przedstawić w następującej formie:

$\mathrm{H}_{3}$ : Fakt niewejścia partii do koalicji rządowej lub jej opuszczenie będzie skutkować odejściem lidera ze stanowiska.

Odnośnie $\mathrm{H}_{3}$ przyjmuję, że niezawiązanie koalicji rządowej może mieć wpływ na odejście lidera, tylko w przypadkach, gdy: 1) przedwyborcze zapowiedzi, bądź powyborcze konsultacje nie doprowadziły do powstania wspólnego rządu; 2) wcześniejszemu partnerowi koalicyjnemu udało się zawiązać koalicję z inną formacją; albo gdy 3) partia opuści koalicję rządową. Takie podejście podyktowane jest faktem, że wyłączone zostają wtedy, szczególnie w przypadkach 1) i 2) czynniki niezależne od lidera. Inaczej jest w przypadku trzech zakreślonych wyżej elementów, na które liderzy partii politycznych mają wpływ. Można zatem oczekiwać, że będą rozliczani za nieskuteczne rozmowy koalicyjne, pominięcie w konsultacjach nad wejściem do rządu, czy ze względu na opuszczenie koalicji. Podejście to bierze pod uwagę istnienie negatywnych przesłanek zawierania koalicji, takich jak głęboki dystans ideologiczny, czy odmienną genezę partii politycznych (kryterium genetyczne). Inaczej mówiąc, uwzględniono mechanizm doboru uczestników koalicji z góry wykluczający utworzenie wspólnego rządu przez niektóre formacje. Słabością tego podejścia jest jednak fakt, że nie uwzględnia strategicznych decyzji o nieutworzeniu koalicji. Takie zjawisko nie jest rzadkością w Europie, a samie partie polityczne mogą być motywowane przez różne czynniki do takiego zachowania (Damgaard, Svensson, 1989; Laver, 1986, s. 39; Strom, 1986). Ta kwestia jednak w przypadku Polski ma ograniczone znaczenie.

Sposób weryfikacji $\mathrm{H}_{2}$ i $\mathrm{H}_{3}$ wymaga komentarza. By przyczynę odejścia lidera móc zasadnie przypisać słabemu wynikowi wyborczemu, przyjmuję że zmiana na stanowisku przewodniczącego musi nastapić w przeciagu 12 miesięcy od daty wyborów parlamentarnych. Rozwiązanie to, choć z natury rzeczy subiektywne, jest podyktowane czasem, jaki jest niezbędny do zorganizowania wyborów partyjnych. W przypadku zmian organizacyjnych stosuje się dłuższy, dwuletni okres (Harmel, Heo, Tan, Janda, 1995, s. 9). 


\section{Rozliczalność liderów przed partiami}

R. M. Punnet wyróżnił trzy główne zmienne dotyczące sposobu wyboru lidera. Są to: 1) tryb w jakim organizuje się wybory partyjne; 2) sposób selekcji kandydatów oraz 3) wielkość podmiotu dokonującego wyboru (ang. selectorate). Na ich podstawie wyróżnione zostały dwa teoretyczne modele dotyczące wyborów wewnątrzpartyjnych, a co z tym idzie, potencjalnej możliwości usunięcia dotychczasowego lidera. W pierwszej, w pełni otwartej i inkluzywnej metodzie, wybory przewodniczącego mogą być zwołane w dowolnym momencie, każdy członek partii może być kandydatem, a sama nominacja ogranicza się do osobistej deklaracji chęci startu w wyborach. Wybór przewodniczącego jest dokonywany w tajnym głosowaniu, w którym mają prawo brać udział wszyscy członkowie partii, a nawet wszyscy uprawnieni do głosowania w wyborach powszechnych. Jest to system zbliżony w swoich założeniach do amerykańskich prawyborów (ang. blanket primary). W drugiej, ekskluzywnej metodzie, wybory mogą odbyć się tylko w przypadku zwolnienia się stanowiska przewodniczącego, bowiem w partii nie funkcjonują wybory przeprowadzane w regularnych odstępach czasu. Grupa potencjalnych kandydatów jest wąska, nominacja leży w rękach ścisłej elity partyjnej, która może także podejmować samą decyzję o wyborze (Punnett, 1992, s. 19). Oba modele są konstruktem teoretycznym i w czystej postaci nie występują we współczesnych partiach politycznych. Stanowią jednak punkt odniesienia, w ramach którego można oceniać rozwiązania przyjęte w poszczególnych ugrupowaniach.

\section{Formalne rozwiązania $w$ statutach partii politycznych}

\section{Prawo i Sprawiedliwość}

Statut PiS przyznaje Kongresowi jako jednemu uprawnionemu podmiotowi możliwość odwołania Prezesa partii. Kongres jest ponadto uprawniony do podejmowanie uchwał w sprawie udzielania absolutorium ustępującemu Prezesowi PiS na podstawie opinii Krajowej Komisji Rewizyjnej. Rada Polityczna partii - będąca najwyższą władzą uchwałodawczą w okresach pomiędzy posiedzeniami Kongresu - może wybrać pełniącego obowiązki Prezesa PiS na okres do trzech miesięcy spośród Wiceprezesów PiS w dwóch przypadkach, gdy Prezes PiS: 1) zrezygnował z funkcji albo utracił lub zawiesił członkostwo w partii; 2) czasowo utracił możliwość sprawowania funkcji. Równocześnie z wyborem pełniącego funkcję Prezesa PiS, Rada Polityczna musi zwołać posiedzenie Kongresu, który ma dokonać wyboru na wakujące stanowisko. Kadencja Prezesa PiS, tak jak innych władz naczelnych partii, trwa cztery lata (Statut partii).

\section{Platforma Obywatelska}

W PO statut w $\S 3$ stanowi, że odwołanie władz wszystkich szczebli w partii odbywa się w tym samy trybie, co wybór. Można zatem przyjąć, że kadencja Przewodniczącego Platformy może ulec skróceniu decyzją Konwencji bezwzględną większością głosów. 
Kadencja władz partii trwa od dwóch do czterech lat, a ich długość określa uchwała Rady Krajowej o zarządzeniu wewnętrznych wyborów (Statut Platformy).

\section{Ruch Palikota}

Statut Ruchu Palikota nie zawiera wyrażonej wprost możliwości usunięcia przewodniczącego partii. Paragraf 17 ust. 8 stanowi jednak, że ,głosowania w sprawach powoływania pełnomocników, wyboru i odwołania członków organów Ruchu PL są tajne". Wydaje się jednak, że zapis ten dotyczy tylko tych organów, co do których statut wyraził wprost możliwość skrócenia kadencji. Jest tak np. w stosunku do Wiceprzewodniczących Zarządu Krajowego, Sekretarza Zarządu Krajowego, Skarbnika Zarządu Krajowego, którzy mogą być odwołani na wniosek Przewodniczącego Ruchu PL bezwzględną większością głosów, w obecności co najmniej połowy osób uprawnionych do głosowania. Można zatem przyjać, że Przewodniczący Ruchu PL nie może zostać usunięty ze stanowiska przed końcem kadencji. W przypadku wystapienia okoliczności, które uniemożliwiają pełnienie funkcji szefowi ugrupowania, Zarząd Krajowy partii ma obowiązek zwołania Kongresu Krajowego nie później niż w terminie 6 miesięcy od dnia rezygnacji lub wystapienia okoliczności, które uniemożliwią pełnienie funkcji Przewodniczącemu Ruchu PL. Ta sama osoba może pełnić tę samą funkcję w partii maksymalnie przez dwie kadencje. Statut stanowi, że długość pełnomocnictw wszystkich organów partyjnych trwa cztery lata (Statut Ruchu).

\section{Polskie Stronnictwo Ludowe}

W PSL Rada Naczelna, będąca najwyższą władzą między Kongresami, jest uprawniona do odwołania Prezesa PSL przed upływem kadencji bezwzględną większością głosów statutowego składu jej członków (do 130). Ponadto, zgodnie z art. 12 ust. 3 i 4 statutu, członkowie władz Stronnictwa, którzy nie uzyskali skwitowania (absolutorium) od właściwych władz lub opuścili bez usprawiedliwienia ponad 50 proc. posiedzeń władz, w których zasiadają, nie mogą kandydować do władz i organów PSL na następną kadencję. Skwitowania ustępującym kolegialnym władzom PSL dokonuje się łącznie na poszczególne składy osobowe tych władz w głosowaniu jawnym, chyba że co najmniej 50 proc. uprawnionych do udzielania skwitowania zażąda głosowania tajnego. Prezes PSL z mocy statutu wchodzi w skład Kongresu, Rady Naczelnej PSL oraz przewodniczy Naczelnemu Komitetowi Wykonawczemu PSL (Statut Polskiego).

\section{Sojusz Lewicy Demokratycznej}

Przewodniczący SLD jako członek z mocy statutu wchodzi w skład Zarządu Krajowego, któremu Konwencja Krajowa raz w trakcie kadencji udziela wotum zaufania. Nieudzielenie wotum zaufania jest równoznaczne z natychmiastowym odwołaniem $\mathrm{z}$ pełnionej funkcji. Wotum zaufania udziela się $\mathrm{w}$ głosowaniu tajnym bezwzględną większością głosów przy obecności co najmniej połowy uprawnionych do głosowania. Konwencja Krajowa jest zwoływana przez Radę Krajową z własnej inicjatywy lub na wniosek Krajowej Komisji Rewizyjnej. Delegatami na Konwencję Krajową są: członkowie Rady Krajowej, członkowie Krajowego Komitetu Wykonawczego, członkowie Kra- 
jowego Sądu Partyjnego, członkowie Krajowej Komisji Rewizyjnej, delegaci, wybrani przez zjazdy wojewódzkie, konwencje wojewódzkie albo rady wojewódzkie w liczbie ustalonej przez Radę Krajową. Kadencja władz w partii trwa cztery lata (Statut Sojuszu).

$* * *$

Należy zauważyć, że nie zawsze podmiot odpowiadający za wybór lidera jest uprawniony do jego odwołania. W PiS i PO liderzy mogą być usunięci ze stanowiska decyzją organów, które ich powołały, w PSL i SLD są to organy partyjne o węższym składzie osobowym. W literaturze przedmiotu zwykle podkreśla się, że zapewnienie odpowiedzialności przed partią musi wiązać się z ograniczeniem liczbowym grupy, która ma prawo usunać lidera (Katz, 2001, s. 281; Mair, 1994, s. 13 i n.; Weller, 1994, s. 133). Oprócz liczebności podmiotu odpowiedzialnego za odwołanie lidera, istotne jest ilu aktorów wewnątrz partii musi współdziałać, aby usunąc lidera, oraz jaka jest ich częstotliwość pracy i trudności z ich zwołaniem. Na podstawie tych kryteriów można dokonać oceny stopnia, w jakim liderzy są narażeni na formalne usunięcie ze stanowiska.

Wszystkie partie, które uzyskały mandaty w wyborach parlamentarnych w $2011 \mathrm{r}$. ograniczają czasem kadencję lidera. We wszystkich ugrupowaniach oprócz Ruchu PL istnieje możliwość usunięcia lidera przed upływem kadencji. W PiS Prezes może być usunięty ze stanowiska decyzją Kongresu, kadencja Przewodniczącego Platformy może być skrócona przez Konwencję, Prezes PSL może być pozbawiony stanowiska przez Radę Naczelną, Przewodniczący SLD w przypadku nieotrzymania wotum zaufania od Konwencji Krajowej SLD traci natychmiast pełnioną funkcję.

W dwóch partiach - PiS i PSL - statutowe ciała mają możliwość wyrażenia opinii dotyczącej działalności dotychczasowego lidera. Statut PiS nie wymienia kryteriów ani nie przewiduje sankcji wiążącej się z negatywną oceną. Inaczej jest w odniesieniu do PSL, w przypadku którego nieudzielenie skwitowania członkom władz i organów PSL wiąże się z brakiem możliwości kandydowania na następną kadencję. Co istotne jednak, skwitowanie w PSL dotyczy ciał kolegialnych, lecz niewyrażonej wprost instytucji Prezesa PSL. Praktyka pokazuje dodatkowo, że skwitowanie ustępujących władz naczelnych następuje po wyborach przewodniczącego partii (Hurkała, 2012).

Biorąc pod uwagę formalne zapisy statusowe, przywódca Ruchu PL cieszy się największą autonomią w porównaniu ze wszystkimi innymi analizowanymi partiami. Przejęcie przywództwa może nastąpić tylko w przypadku zakończenia czteroletniej kadencji dotychczasowego przywódcy i wygrania wyborów w partii przez konkurenta do władzy. Warto jednak zaznaczyć, że ta sama osoba może pełnić funkcję Przewodniczącego Ruchu PL przez maksymalnie dwie kadencje. Podobne przepisy nie funkcjonują w innych partiach. Pozycja Przewodniczącego SLD - podobnie jak w Ruchu PL - jest stosunkowo silna, bowiem Konwencja Krajowa SLD ma prawo udzielenia tylko raz w trakcie swojej czteroletniej kadencji wotum zaufania. W PiS i PO decyzja o odwołaniu należy do partyjnych Kongresów, jednak ich tryb zwoływania i obradowania znacznie utrudnia podjęcie decyzji o usunięciu lidera ze stanowiska ${ }^{1}$. Pozbawienie stanowiska przywódcy partii jest

${ }^{1}$ W PiS Rada Polityczna może zwołać posiedzenie Kongresu PiS w trakcie kadencji, uchwałą podjętą większością 2/3 głosów, na wniosek, co najmniej 21 Zjazdów Okręgowych. Krajowa Konwencja 
stosunkowo najmniej utrudnione w PSL. O takiej kwalifikacji decyduje skład podmiotu, który ma prawo odwołać Prezesa oraz tryb jego pracy. Rada Naczelna jest stosunkowo wąskim ciałem w porównaniu do Kongresu, gdyż w jej skład wchodzi maksymalnie 130 członków. Problem kworum niezbędnego do podjęcia decyzji jest przez to ograniczony. Dodatkowo, zgodnie ze statutem, Rada Naczelna obraduje stosunkowo często - co najmniej raz na kwartał. Przewodniczący Rady Naczelnej PSL zobowiązany jest zwołać jej posiedzenie na żądanie co najmniej 1/3 członków Rady, bądź na skutek uchwały Naczelnego Komitetu Wykonawczego PSL.

W tab. 1 wymieniono przesłanki odejścia liderów partii politycznych w Polsce. Zostały one pogrupowane zgodnie ze schematem klasyfikacyjnym obejmującym sześć kategorii zaproponowanym przez Williama Cross'a i André Blais'a (2011, s. 135). Analiza przyczyn ustapienia ze stanowiska polskich przywódców pozwala na poszerzenie tego schematu o kolejne dwie kategorie. Zmiana (bądź ustanie) przywództwa w partii może się zatem wiązać z: 1) dobrowolnym odejściem; 2) odejściem pod presją; 3) rezygnacją ze względu na różnicę zdań odnośnie jednej określonej kwestii; 4) zakończeniem działalności partii politycznej; 5) śmiercią przywódcy; 6) formalnym odwołaniem; 7) nieubieganiem się o reelekcję; 8) niewybraniem na kolejną kadencję. Trudności może budzić przyporządkowanie przypadków do pierwszej i drugiej kategorii oraz częściowo do siódmej, a więc dokonanie subiektywnej oceny, czy odejście było wymuszone. Za dobrowolne odejście przyjęto rezygnację lidera w przypadku, gdy nie była wywierana presja, by odszedł ze stanowiska (W. Cross, Blais, 2011, s. 135).

Tabela 1

Przyczyny odejścia ze stanowiska liderów partii politycznych w Polsce

\begin{tabular}{||l|c|c|l||}
\hline \multicolumn{1}{||c|}{ Przywódca/Partia } & $\begin{array}{c}\text { Data } \\
\text { wyboru }\end{array}$ & $\begin{array}{c}\text { Data } \\
\text { odejścia }\end{array}$ & \multicolumn{1}{c||}{ Przesłanka odejścia } \\
\hline \multicolumn{1}{||c|}{1} & 2 & 3 & 4 \\
\hline \multicolumn{5}{|c||}{ PiS } \\
\hline Lech Kaczyński & 29.05 .2001 & 18.01 .2003 & dobrowolne odejście \\
\hline Maciej Płażyński & 18.10 .2001 & 9.04 .2003 & $\begin{array}{l}\text { rezygnacja ze względu na różnicę zdań odnoś- } \\
\text { nie jednej określonej kwestii }\end{array}$ \\
\hline \multicolumn{5}{|c||}{ PSL } \\
\hline Roman Bartoszcze & 5.05 .1990 & 29.06 .1991 & nieubieganie się o reelekcję \\
\hline Waldemar Pawlak & 29.06 .1991 & 11.10 .1997 & formalne odwołanie \\
\hline Jarosław Kalinowski & 11.10 .1997 & 16.03 .2004 & odejście pod presją \\
\hline Janusz Wojciechowski & 16.03 .2004 & 29.01 .2005 & $\begin{array}{l}\text { rezygnacja ze względu na różnicę zdań odnoś- } \\
\text { nie jednej określonej kwestii }\end{array}$ \\
\hline Waldemar Pawlak & 29.01 .2005 & 17.11 .2012 & niewybranie na kolejną kadencję \\
\hline \multicolumn{5}{|c|}{ SLD } \\
\hline Leszek Miller & 15.04 .1999 & 6.04 .2004 & odejście pod presją \\
\hline \hline
\end{tabular}

Platformy może być zwołana decyzją Zarządu Krajowego. Konwencja może podejmować uchwały, jeśli weźmie w niej udział co najmniej $1 / 3$ uprawnionych do głosowania. 


\begin{tabular}{||l|c|c|l||}
\hline \multicolumn{1}{|c|}{1} & 2 & 3 & \multicolumn{1}{c||}{4} \\
\hline Krzysztof Janik & 6.04 .2004 & 18.12 .2004 & niewybranie na kolejną kadencję \\
\hline Józef Oleksy & 18.12 .2004 & 29.05 .2005 & odejście pod presją \\
\hline Wojciech Olejniczak & 29.05 .2005 & 31.05 .2008 & niewybranie na kolejną kadencję \\
\hline Grzegorz Napieralski & 31.05 .2008 & 10.12 .2011 & odejście pod presją \\
\hline \hline
\end{tabular}

Źródło: Opracowanie własne na podstawie prasy.

Biorąc pod uwagę dane zawarte $\mathrm{w}$ tab. $1, \mathrm{H}_{1}$ uzyskała niewielkie wsparcie empiryczne. W PSL na pięć zmian na stanowisku prezesa, każda została zakwalifikowana w ramach odrębnej z wyznaczonych kategorii. Ludowcom udało się raz odwołać lidera ze stanowiska. Oprócz tego w 1991 r. dwukrotnie próbowano usunąć ze stanowiska ówczesnego prezesa Romana Bartoszcze. W kwietniu 40 członków Rady Naczelnej opowiedziało się za jego odwołaniem, przeciw głosowało 35. Niespełniony został zatem funkcjonujący w owym czasie wymóg uzyskania 2/3 głosów członków Rady (Bartoszcze, 1991). Ponad miesiąc później doszło do kolejnego głosowania nad pozbawieniem R. Bartoszcze stanowiska. Spośród 110 członków Rady Naczelnej 53 chciało jego odejścia, 17 poparło prezesa PSL, 10 wstrzymało się od głosu. Ponownie nie został zatem spełniony wymóg uzyskania 2/3 głosów członków Rady. Sam prezes odmówił rezygnacji, podjęto zatem decyzję o jego zawieszeniu, która zresztą nie miała oparcia w zapisach statutowych (Naszkowska, 1991a). W trakcie przyspieszonych wyborów wewnętrznych w czerwcu 1991 r. R. Bartoszcze nie ubiegał się ponownie o przywództwo. W czasie Kongresu w głosowaniu nad wotum nieufności, z 500 delegatów za prezesem PSL opowiedziało się tylko 30 głosujących (Jagieliński, 1991). W momencie, gdy odbywały się obrady, R. Bartoszcze poinformował dziennikarzy, że na Kongres nie przybył, gdyż delegaci zostali na niego wytypowani, a nie demokratycznie wybrani (Naszkowska, 1991b).

Presja mająca na celu skłonienie do rezygnacji była dominującą przyczyną zakończenia kadencji lidera w SLD. W Sojuszu na pięć zmian na stanowisku przewodniczącego, liderzy trzy razy odchodzili pod presją partii, dwa razy nie udało im się wygrać ponownie wewnątrzpartyjnych wyborów. Wpływ rozwiązań instytucjonalnych na odejście lidera zaznaczył się jedynie w rezygnacji Józefa Oleksego w 2005 r. z przewodniczenia Sojuszowi. W obliczu prawdopodobnego nieotrzymania wotum zaufania, na osiem dni przed Konwencją Krajową ustąpiły całe władze SLD: przewodniczący Sojuszu J. Oleksy, jego zastępcy - Katarzyna Piekarska, Grzegorz Napieralski, Jerzy Szmajdziński i Wiesław Szczepański, sekretarz generalny Marek Dyduch oraz szef klubu parlamentarnego Krzysztof Janik (Olczyk, 2005). Zatem tylko w tym przypadku można mówić o wpływie rozwiazzań statutowych, które doprowadziły do zmiany na stanowisku lidera. Ogólnie rzecz biorąc, w SLD w zasadzie funkcjonują tylko pozastatutowe mechanizmy odsuwania liderów od władzy.

W przypadku dwóch partii o rodowodzie postsolidarnościowym, a więc PO i PiS, doszło do zmiany przywództwa w partii. W obu przypadkach było ono dobrowolne. Ze względu na brak wyraźnej presji, odejście Macieja Płażyńskiego zostało zakwalifikowane jako dobrowolne. W świetle słów byłego polityka PO, Jana Rokity, sytuacja wyglądała raczej na wymuszone odejście (Krasowski, Rokita, 2013). M. Płażyński swoje odejście thumaczył inną wizją partii, która miała być według niego otwarta na elektorat 
miejski i wiejski. PO jego zdaniem zamknęła się w kręgu wyborców „lepiej wykształconych i zamożniejszych".

„Wśród elektoratu PO - tłumaczył w wywiadzie M. Płażyński - przeważają poglądy centrowe. Dlatego na lidera tej partii bardziej pasują Tusk i Olechowski. Nadszedł czas, żeby na czele Platformy stanęła osoba, która swoją twarzą będzie wzmacniać jej centrowy charakter. [...] Zrezygnowałem nie dlatego, iż ktoś mnie do tego namawiał, czy też z obawy, że przegram wybory. Gdybym był zadowolony w pełni z Platformy, to nie rezygnowałbym" (Gawryś, Bielakowski, 2003).

Odejście Lecha Kaczyńskiego ze stanowiska prezesa PiS wiązało się z jego wygraną w wyborach na prezydenta Warszawy, zatem kwalifikacja tego przypadku nie natrafiła na problemy interpretacyjne.

Presja ze strony ugrupowania, ze względu na zapisy statutowe zapewniające silną pozycję lidera w partii, były dominującą przyczyną odejść liderów w SLD. Ludowcy jako jedyni sięgali po statutowe mechanizmy zmian na stanowisku przywódcy. Konkludując tę część rozważań, można zatem uznać $\mathrm{H}_{1}$ znalazła wsparcie empiryczne.

\section{Wpływ wyniku wyborczego na zdolność liderów do utrzymania się na stanowisku}

W tab. 2 zaprezentowano wyniki wyborów parlamentarnych. Uwzględniono tylko tych liderów, za kadencji których partie brały udział w wyborach. Analiza przedstawionych danych wskazuje na stosunkowo czytelny wzorzec odchodzenia ze stanowiska przywódców, którzy doprowadzili do słabszego wyniku wyborczego mierzonego mniejszym poparciem społecznym niż we wcześniejszej elekcji. Należy zaznaczyć, że niewielka liczba przypadków pozwala na ograniczone generalizacje.

Tabela 2

Wpływ wyników wyborów parlamentarnych na utrzymanie się liderów partii politycznych na stanowisku

\begin{tabular}{||l|c|c|c|c|c||}
\hline \multicolumn{1}{|c|}{ Przywódca } & $\begin{array}{c}\text { Data } \\
\text { wyborów }\end{array}$ & $\begin{array}{c}\text { Zmiana popar- } \\
\text { cia (pkt proc.) }\end{array}$ & $\begin{array}{c}\text { Zmiana liczby } \\
\text { mandatów }\end{array}$ & $\begin{array}{c}\text { Rząd vs. } \\
\text { opozycja }\end{array}$ & Odejście \\
\hline Donald Tusk (PO) & 9.10 .2011 & $-2,33$ & -2 & rząd & nie \\
\hline Grzegorz Napieralski (SLD) & 9.10 .2011 & $-4,91$ & -26 & opozycja & tak \\
\hline Jarosław Kaczyński (PiS) & 9.10 .2011 & $-2,22$ & -9 & opozycja & nie \\
\hline Waldemar Pawlak (PSL) & 21.09 .1997 & $-8,09$ & -105 & opozycja & tak \\
\hline Waldemar Pawlak (PSL) & 9.10 .2011 & $-0,55$ & -3 & rząd & tak \\
\hline Wojciech Olejniczak (SLD) & 21.10 .2007 & $+1,84$ & -2 & opozycja & tak \\
\hline \hline
\end{tabular}

Źródło: Opracowanie własne na podstawie prasy i danych Państwowej Komisji Wyborczej, www.pkw.gov.pl.

PO w 2011 r. wygrała wybory parlamentarne i utworzyła koalicję gabinetową z PSL. Platformie udało się w ten sposób jako pierwszej partii po przemianach 1989 r. uzyskać dwukrotnie z rzędu najwyższy wynik w elekcji do Sejmu i, dodatkowo, ponownie wejść w skład rządu. Niewielki spadek poparcia (poniżej 2,5 pkt proc.) w wyborach przełożył 
się na utratę dwóch mandatów w Sejmie. Nie przeszkodziło to jednak w zawiązaniu koalicji rządzącej z PSL, choć trzeba zaznaczyć, że obie partie dysponowały w momencie powoływania rządu niewielką większością głosów. Można zatem przyjąć, że spadek poparcia wyborczego nie może być zasadnie oceniony jako porażka wyborcza.

Inaczej przedstawia się kwestia wyniku wyborczego PiS w tej samej elekcji. Ugrupowanie to utrzymało drugie miejsce $w$ wyścigu wyborczym, uzyskując niewiele mniejsze poparcie niż w wyborach z 2007 r., co przełożyło się na utratę dziewięciu mandatów w stosunku do wcześniejszych wyborów. Mimo utrzymania przez PiS pozycji największej partii opozycyjnej, znacznie przy tym deklasującej poparciem inne ugrupowania opozycyjne, wydaje się zasadne zakwalifikowanie wyniku wyborczego tej partii jako porażki. W 2007 r. doszło do skrócenia kadencji Sejmu i rozpisania przedterminowych wyborów. SLD pod przywództwem Wojciecha Olejniczaka startował w koalicji Lewica i Demokraci (LiD) z Unią Pracy, Partią Demokratyczna - demokraci.pl (PD) oraz powstałą w wyniku rozłamu w SLD Socjaldemokracją Polską (SdPL) Marka Borowskiego. W wyborach parlamentarnych przeprowadzonych 21 października 2007 r. koalicja LiD uzyskała 13,15 proc. głosów i 52 mandaty w Sejmie, przegrywając rywalizację z PO cieszącą się prawie 42 proc. poparciem i PiS z 32,11 proc. głosów. Żaden z kandydatów LiD do Senatu nie uzyskał mandatu.

Jak donosiły media, na pierwszym po wyborach posiedzeniu Zarządu Krajowego SLD sekretarz generalny partii Grzegorz Napieralski ostro skrytykował wynik wyborczy Sojuszu i mówił o konieczności zwołania kongresu. Były przewodniczący SLD L. Miller, który według prasy wraz z J. Oleksym miał wspierać G. Napieralskiego, mówił wtedy: „Powinien [G. Napieralski - przyp. M. R.] walnąć pięścią w stół, zwołać konferencję prasową i zażądać jak najszybszego zwołania kongresu i rozliczenia kierownictwa partii z ostatnich wyborów”. Konieczność zmian w partii dostrzegał także J. Oleksy. „Niepokojące jest przejście liderów LiD do porządku dziennego nad zaskakującymi wynikami wyborów" - poinformował dziennikarzy były lider SLD. Niezadowolenie w partii musiała także budzić nieefektywna współpraca z PD i SdPL, gdyż to Sojusz jako silniejszy podmiot poniósł największe koszty współpracy (Krysiak, 2007).

W miesiąc po wyborach Rada Krajowa partii zdecydowała, że w czerwcu 2008 r. odbędzie się kongres, na którym zostaną wybrane nowe władze. W głosowaniu dotychczasowy sekretarz generalny partii G. Napieralski wygrał niewielką większością - dostał 231 głosy, W. Olejniczak - 210, a więc tylko o 21 mniej (Gielewska, Stróżyk, Zalesiński, 2008).

W. Olejniczak został odsunięty ze stanowiska po siedmiu miesiącach od przeprowadzenia wyborów. Pomimo krytycznie ocenianego wyniku wyborczego, G. Olejniczak mimo wszystko uzyskał silne poparcie w wewnętrznych wyborach. Fakt ich przeprowadzenia świadczy jednak silnie na korzyść interpretacji, że uzyskany wynik Sojusz uznał za niezadowalający, mimo zyskania blisko 2 pkt proc. głosów, które jednak nie przełożyły się na zwiększenie liczby mandatów. Wydaje się zatem zasadne zmodyfikowanie założeń dotyczących konceptualizacji wyniku wyborczego i zakwalifikowanie odejścia jako spowodowanego słabym rezultatem w elekcji do Sejmu.

PSL kierowane przez W. Pawlaka w wyborach do Sejmu we wrześniu 1997 r. zdobyło tylko 7,31 proc. głosów, co przełożyło się na 27 mandatów. Ludowcy stracili ponad 100 mandatów w Sejmie i ponad 30 w Senacie. Większość organizacji wojewódzkich Stronnictwa od razu po wyborach opowiedziała się za odwołaniem liderów partii. Sam 
W. Pawlak nie widział powodów do podania się do dymisji, choć przyznał, że wybory dla PSL skończyły się porażką. Dzień przed posiedzeniem Rady Naczelnej minister rolnictwa z ramienia PSL Jarosław Kalinowski zapowiedział, że jest gotowy objąć przywództwo w partii. Miesiąc po wyborach Rada Naczelna PSL niewielką większością głosów usunęła W. Pawlaka z pełnionej funkcji. Za jego odwołaniem głosowało 64 z 112 członków Rady Naczelnej, co oznacza że o wyniku głosowania zdecydowały dwa głosy (Lizut, 1997; ml, 1997; Sieklucki, 2006, s. 83; Wielowieyska, Lizut, 1997). „Tak to już jest w polityce. Ponieśliśmy porażkę w wyborach" - tak tłumaczył przyczynę usunięcia W. Pawlaka nowo wybrany prezes PSL Jarosław Kalinowski (Lizut, 1997).

Kierowane przez W. Pawlaka PSL uzyskało w wyborach parlamentarnych w $2011 \mathrm{r}$. tylko 8 proc. głosów, znacznie mniej niż oczekiwano, zwłaszcza po sukcesie w wyborach samorządowych w 2010 r., w których Stronnictwo uzyskało ponad 16 proc. poparcie. Mimo słabego wyniku wyborczego w partii nie doszło do rozliczeń ze względu na szybkie zawarcie koalicji z PO. Koalicja rządowa ze względu na wynik wyborczy dysponuje w Sejmie większością tylko czterech głosów (Paradowska, 2012).

Po ponad 13 miesiącach od elekcji do Sejmu W. Pawlakowi nie udało się utrzymać przywództwa w partii. Na kongresie nowego lidera partii wybrano przewagą zaledwie 17 głosów: Janusz Piechociński zdobył 547 głosów, na W. Pawlaka głosowało 530 delegatów. Ze względu na przekroczenie założonego na wstępie 12 miesięcznego okresu, w ramach którego lider musi odejść ze stanowiska, przypadek PSL z 2012 r. nie działa na niekorzyść $\mathrm{H}_{2}$.

Ogólnie rzec biorąc, $\mathrm{H}_{2}$ uzyskała silne wsparcie empiryczne. Na pięć przypadków słabego wyniku wyborczego (wykluczając wynik wyborczy PO z 2011 r.), czterokrotnie mieliśmy do czynienia z utratą stanowiska przez lidera partii. Wyjątkiem jest utrzymanie stanowiska przez J. Kaczyńskiego po wyborach w 2011 r.

Biorąc pod uwagę dane zawarte w tab. 2 należy uznać, że $\mathrm{H}_{3}$ nie uzyskała potwierdzenia empirycznego. Niekorzystna sytuacja na arenie rządowej nie była bezpośrednim czynnikiem powodującym odejście lidera ze stanowiska. Obrazuje to przykład PSL z 1995 i 2003 r., a także sytuacja tej partii po wyborach z 2011 r. Do pewnego stopnia na korzyść $\mathrm{H}_{3}$ działa odejście L. Millera w $2004 \mathrm{r}$.

W marcu 1995 r. ze względu na narastający konflikt W. Pawlaka z jednej strony z prezydentem Lechem Wałęsą, a z drugiej strony z SLD będącym partnerem koalicyjnym, lider PSL został pozbawiony funkcji premiera w wyniku przegłosowania konstruktywnego wotum nieufności (por. Dudek, 2007, s. 296; Jednaka, 2002, s. 129). PSL pozostało jednak w koalicji gabinetowej. Z kolei w 2003 r. doszło do konfliktu w koalicji SLD-PSL w wyniku którego ludowcy zostali usunięci z rządu (Migalski, Wojtasik, Mazur, 2006, s. 234). W tych dwóch zarysowanych przypadkach nie doszło do udanej próby odsunięcia przywódców partyjnych od władzy. Inny był jednak ich kontekst sytuacyjny. O ile w przypadku W. Pawlaka, jego usunięcie z funkcji premiera było związane z konfliktami wewnątrz koalicji, które zresztą sam często prowokował (Sieklucki, 2006, s. 51), to w przypadku zerwania koalicji gabinetowej z PSL przez SLD, wydaje się, że była to strategiczna decyzja samego Sojuszu, a kwestia ustaw o winietach i biopaliwach stała się jedynie wygodnym pretekstem do bezpośredniego usunięcia ludowców z rządu (Dudek, 2007, s. 454-455; Migalski, Wojtasik, Mazur, 2006, s. 234).

Zasadniczo odmienna sytuacja miała miejsce w przypadku odejścia L. Millera w 2004 r. $\mathrm{z}$ funkcji premiera. Zgodnie z kalendarzem wyborczym wybory do Sejmu miały się od- 
być w 2005 r. Sojusz w owym czasie tracił silnie poparcie społeczne. Leszek Miller przestał być zatem postrzegany jako gwarant wyborczego zwycięstwa swojej partii i, będąc szefem Rady Ministrów, został zmuszony do złożenia teki premiera, a następnie do rezygnacji z przywództwa w SLD.

Przykłady te pokazuja, że stanowisko szefa rządu nie gwarantuje autonomii w partii. Słabnący przywódca podatny jest na naciski wewnątrzpartyjne zmierzające do odsunięcia go ze stanowiska. Był to casus L. Millera. W przypadku W. Pawlaka nawet doprowadzenie do zawiązania koalicji nie uchroniło go od utraty stanowiska. Można zatem ogólnie przyjąć, że niezadowalająca aktywność na arenie rządowej przejawiająca się niewejściem w skład koalicji rządzącej, bądź jej opuszczeniem, nie wpływa bezpośrednio na zdolność liderów do utrzymania się na stanowisku.

\section{Zamiast podsumowania}

Wykres 1 obrazuje długość pełnienia funkcji przez liderów ugrupowań politycznych w Polsce ${ }^{2}$. Średnia arytmetyczna z 20 obserwacji sugeruje, że liderzy przeciętnie kierują partią około trzech i pół roku (dokładna wartość wynosi 3,59), jednak wysoka wartość odchylenia standardowego od średniej $(3,19)$ wskazuje na fakt istnienia znacznych różnic

\section{Wykres 1. Czas trwania na stanowisku liderów partii politycznych w Polsce}

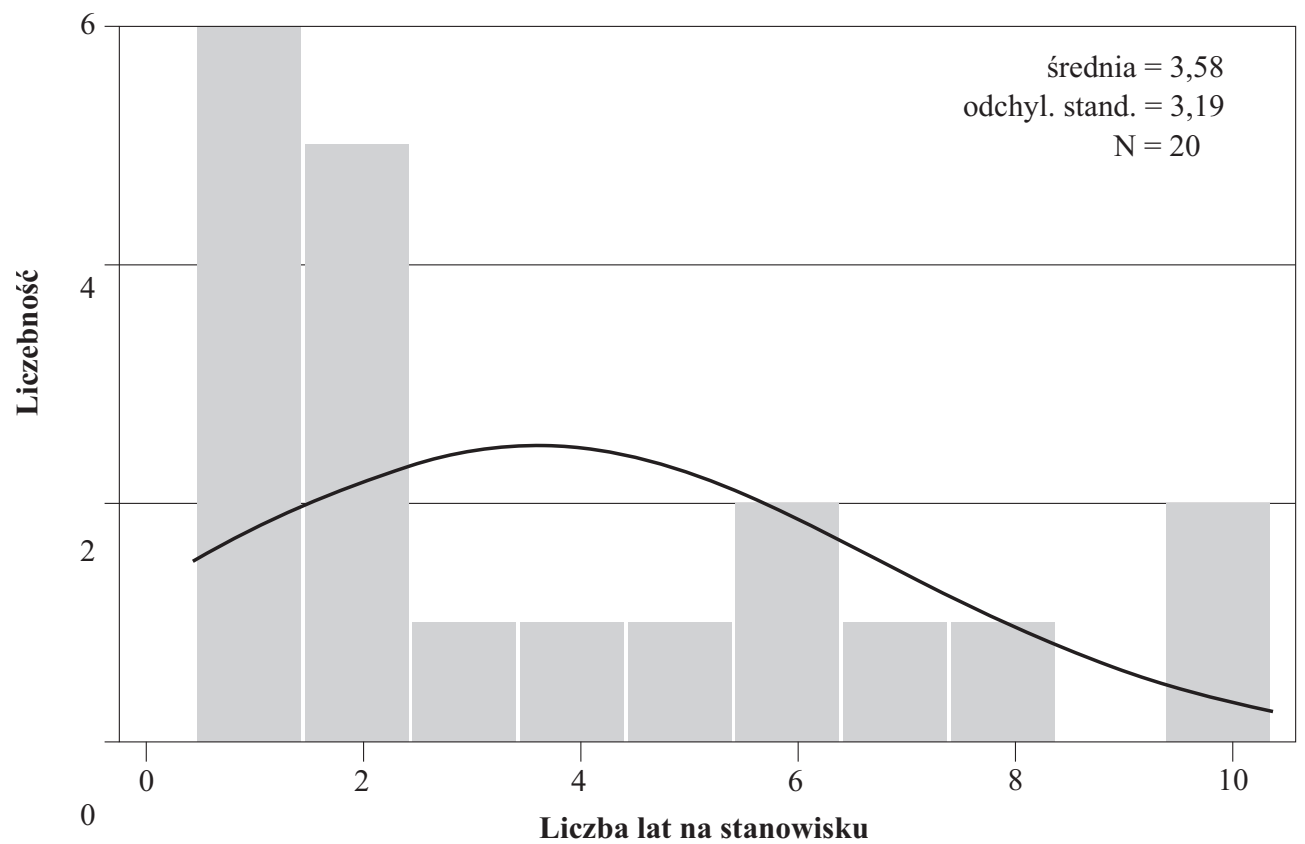

Źródło: Opracowanie własne.

${ }^{2}$ Stan na 31 maja 2013 r. Uwzględniono również liderów poprzedniczki SLD - Socjaldemokracji Rzeczypospolitej Polskiej. 
w długości pełnionych kadencji. W celach analitycznych czas trwania na stanowisku można podzielić na od okres do 12 lat, z przedziałami co dwa lata. Takie ujęcie pokazuje, że kadencja liderów w większości obserwacji (11 przypadków, 55 proc.) nie sięga dwóch lat, po dwie obserwacje znajdują się w przedziałach 2-4 lata, 4-6 i 10-12 lat, składając się łącznie na 30 proc. przypadków; w trzech przypadkach (15 proc.) przywódcy kierowali partią 6-8 lat. Dla porównania w ustabilizowanych demokracjach westminsterskich czas trwania na stanowisku większości przywódców partyjnych wynosi od dwóch do dziesięciu lat (Cross, Blais, 2012, s. 91). W Polsce najkrócej, bo tylko pięć miesięcy i 11 dni, przywódcą partii był J. Oleksy (SLD), najdłużej bez przerwy kierowali swoimi ugrupowaniami (ponad 10 lat), Donald Tusk (PO) i Jarosław Kaczyński (PiS), którzy objęli swoje stanowisko w 2003 r. Sumując jednak okres sprawowania przywództwa w jednej partii, W. Pawlak w latach 1991-1997, a następnie 2005-2012 był liderem PSL przez łącznie ponad 14 lat.

\section{Bibliografia}

Andrews J. T., Jackman R. W. (2008), If Winning Isn't Everything, Why Do They Keep Score? Consequences of Electoral Performance for Party Leaders, „British Journal of Political Science”, t. 38 , nr 4 .

Bartoszcze - kruchy lider (1991), „Gazeta Wyborcza” z dnia 29.04.1991 r.

Bille L. (1997), Leadership Change and Party Change: The Case of the Danish Social Democratic Party, 1960-95, „Party Politics”, t. 3, nr 3.

Bynander F., 't Hart P. (2007), The Politics of Party Leader Survival and Succession: Australia in Comparative Perspective, „Australian Journal of Political Science”, t. 42, nr 1.

Cross W. P., Blais A. (2012), Politics at the Centre: The Selection and Removal of Party Leaders in the Anglo Parliamentary Democracies, Oxford University Press, Oxford.

Cross W., Blais A. (2011), Holding Party Leaders to Account: The Westminster Cases, w: How Power Changes Hands: Transition and Succession in Government, red. P. 't Hart, J. Uhr, Palgrave Macmillan, Basingstoke.

Damgaard E., Svensson P. (1989), Who governs? Parties and policies in Denmark, „European Journal of Political Research", t. 17, nr 6.

Dudek A. (2007), Historia polityczna Polski 1989-2005, Wydawnictwo Arcana, Kraków.

Flyvbjerg B. (2005), Pięć mitów o badaniach typu studium przypadku, „Studia Socjologiczne”, nr 2.

Gawryś F., Bielakowski C. (2003), W pułapce Unii Wolności. Rozmowa z Maciejem Płażyńskim, „Rzeczpospolita” z dnia 10.04.2003 r.

Gielewska A., Stróżyk J., Zalesiński Ł. (2008), Sojusz pod nowymi sterami, „Rzeczpospolita” z dnia 2.06.2008 r.

Harmel R., Janda K. (1994), An Integrated Theory of Party Goals and Party Change, „Journal of Theoretical Politics", t. 6, nr 3.

Harmel R., Heo U., Tan A., Janda K. (1995), Performance, Leadership, Factions and Party Change: An Empirical Analysis, „West European Politics”, t. 18, nr 1.

Helboe Pedersen H. (2012), What do Parties Want? Policy versus Office, „West European Politics”, t. 35 , nr 4 .

Horiuchi Y., Laing M., 't Hart P. (2012), Hard Acts to Follow: Predecessor Effects on Party Leader Survival, „Party Politics” (artykuł dostępny online).

Hurkała T. (2012), Polska zastuguje na lepsza politykę, http://www.zielonysztandar.com/2012/11/ polska-zasluguje-na-lepsza-polityke/, 31.05.2013. 
Jagieliński wygrał z Bartoszcze (1991), „Gazeta Wyborcza” z dnia 1.07.1991 r.

Jednaka W. (2002), Proces tworzenia gabinetów koalicyjnych (1989-2001), w: Demokratyzacja w III Rzeczypospolitej, red. A. Antoszewski, Wydawnictwo Uniwersytetu Wrocławskiego, Wrocław.

Katz R. S. (2001), The Problem of Candidate Selection and Models of Party Democracy, „Party Politics", t. 7, $\mathrm{nr} 3$.

Katz R. S., Mair P. (2002), The Ascendancy of the Party in Public Office: Party Organizational Change in Twentieth-Century Democracies, w: Political parties: old concepts and new challenges, red. R. Gunther, J. R. Montero, J. J. Linz, Oxford University Press, Oxford.

Katz R. S., Mair P. (2009), The Cartel Party Thesis: A Restatement, „Perspectives on Politics”, t. 7, nr 4.

Kitschelt H. (2000), Citizens, Politicians, and Party Cartellization: Political Representation and State Failure in Post-industrial Democracies, „European Journal of Political Research”, t. 37, nr 3.

Krasowski R., Rokita J. (2013), Anatomia przypadku, Wydawnictwo Czerwone i Czarne, Warszawa.

Krysiak P. (2007), Sprzqtanie po Kwaśniewskim, „Wprost”, nr 37.

Laing M., 't Hart P. (2011), Seeking and Keeping the Hot Seat: A Comparative Analysis of Party Leader Successions, w: How Power Changes Hands: Transition and Succession in Government, red. P. 't Hart, J. Uhr, Palgrave Macmillan, Basingstoke.

Laver M. (1986), Between Theoretical Elegance and Political Reality: Deductive Models and Cabinet Coalitions in Europe, w: Coalitional Behaviour in Theory and Practice: An Inductive Model for Western Europe, red. G. Pridham, Cambridge University Press, Cambridge.

Lijphart A. (1971), Comparative Politics and the Comparative Method, „The American Political Science Review", t. 65, nr 3.

Lizut M. (1997), Lzy Pawlaka, „Gazeta Wyborcza” z dnia 13.10.1997 r.

Lizut M. (1997), Trzeba młodej krwi. Rozmowa z Jarosławem Kalinowskim, prezesem PSL, „Gazeta Wyborcza" z dnia 13.10.1997 r.

Lowndes V. (2006), Instytucjonalizm, w: Teorie i metody w naukach politycznych, red. D. Marsh, G. Stoker, Wydawnictwo Uniwersytetu Jagiellońskiego, Kraków.

Loxbo K. (2013), The fate of intra-party democracy: Leadership autonomy and activist influence in the mass party and the cartel party, „Party Politics”, t. 19, nr 4.

Mair P. (1994), Party Organizations: From Civil Society to the State, w: How Parties Organize: Change and Adaptation in Party Organizations in Western Democracies, red. R. S. Katz, P. Mair, SAGE Publications, London.

Mair P. (1997), Party System Change: Approaches and Interpretations, Clarendon Press, Oxford.

McAnulla S. (2010), Forced Exits: Accounting for the Removal of Contemporary Party Leaders, „The Political Quarterly", t. 81, nr 4.

McSweeney D. (1999), Changing the Rules Changed the Game: Selecting Conservative Leaders, „Party Politics”, t. 5, nr 4.

Migalski M., Wojtasik W., Mazur M. (2006), Polski system partyjny, Wydawnictwo Naukowe PWN, Warszawa.

ml. (1997), Kto porzqdzi w PSL?, „Gazeta Wyborcza” z dnia 11.10.1997 r.

Müller W. C., Strřm K. (red.), (1999), Policy, Office, or Votes?: How Political Parties in Western Europe Make Hard Decisions, Cambridge University Press, Cambridge.

Naszkowska K. (1991a), Bartoszcze źle stużyt, „Gazeta Wyborcza” z dnia 31.05.1991 r.

Naszkowska K. (1991b), O PSL zmianie prezesa i trzech muszkieterach, „Gazeta Wyborcza” z dnia 1.07.1991 r.

Olczyk E. (2005), Lewica w rozsypce, „Rzeczpospolita” z dnia 23.05.2005 r.

Państwowa Komisja Wyborcza, www.pkw.gov.pl, 31.05.2013.

Paradowska J. (2012), Tańce ludowe, „Polityka”, nr 7. 
Poguntke T., Webb P. (2005), The Presidentialization of Contemporary Democratic Politics: Evidence, Causes and Consequences, w: The presidentialization of politics: a comparative study of modern democracies, red. T. Poguntke, P. Webb, Oxford University Press, New York.

Punnett R. M. (1992), Selecting the Party Leader: Britain in Comparative Perspective, Harvester Wheatsheaf, London.

Quinn T. (2005), Leasehold or Freehold? Leader-Eviction Rules in the British Conservative and Labour Parties, „Political Studies”, t. 53, nr 4.

Radecki M. (2012), Czy w Polsce istnieje kartel partii politycznych?, „Świat Idei i Polityki”, t. 11.

Raunio T. (2002), Why European Integration Increases Leadership Autonomy within Political Parties, „Party Politics”, t. 8, nr 4.

Sieklucki D. (2006), Partie lewicy i centrolewicy w polskim systemie partyjnym. Aktywność SLD, PSL i UP na polskiej scenie politycznej, Wydawnictwo Uniwersytetu Jagiellońskiego, Kraków.

Statut partii Prawo i Sprawiedliwość przyjęty podczas II Kongresu Prawa i Sprawiedliwości w Warszawie w dniu 26 września 2009 r.

Statut Platformy Obywatelskiej. Tekst jednolity Statutu obowiązujący na dzień 25.09.2010 r.

Statut Polskiego Stronnictwa Ludowego. Teks ujednolicony obejmujący zmiany uchwalone na $\mathrm{X}$ Kongresie PSL w dniu 8 listopada 2008 r.

Statut Ruchu Palikota (2012).

Statut Sojuszu Lewicy Demokratycznej w brzmieniu uchwalonym na V Kongresie SLD. Warszawa, 28 kwietnia $2012 \mathrm{r}$.

Strom K. (1986), Deferred Gratification and Minority Governments in Scandinavia, „Legislative Studies Quarterly", t. 11, nr 4.

Weller P. (1983), The Vulnerability of Prime Ministers: A Comparative Perspective. „Parliamentary Affairs", t. 36, nr 1 .

Weller P. (1994), Party Rules and the Dismissal of Prime Ministers: Comparative Perspectives from Britain, Canada and Australia, „Parliamentary Affairs”, t. 47, nr 1.

Wielowieyska D., Lizut M. (1997), Pawlak do soboty? „Gazeta Wyborcza” z dnia 10.10.1997 r.

\section{The reasons why the leaders of political parties are replaced. The Polish case}

\section{Summary}

The paper deals with the issue of the reasons for the replacement of the leaders of political parties in Poland. It takes into consideration the two main factors that have been agreed by academic circles to be decisive for the duration of a leader's staying in his/her post. Firstly, an analysis of the formal procedures regulating the dismissal of the leaders of political parties provided by the party statutes is conducted. Secondly, the paper presents the influence election results (the number of votes won and the fact of establishing a government coalition or failing to do so) have on the leaders' ability to keep their post. The analysis encompasses the political parties that won a mandate in the 2011 parliamentary elections, that is Law and Justice (PiS), Civic Platform (PO), Polish People's Party (PSL), Palikot's Movement (RP) and the Democratic Left Alliance (LSD). The paper discusses the topic of the replacement of the leaders since the beginnings of these parties. The analysis reveals a strong influence of election results and statutory provisions on the duration of respective leaders' terms. The fact of entering into a government coalition, or failing to do so, does not have a significant influence on the leaders' maintaining their position.

Key words: leadership, political parties, elections, Poland, Central and Eastern Europe 